\title{
Sulphasalazine inhibition of human granulocyte activation by inhibition of second messenger compounds
}

\author{
Gunnar Carlin, Richard Djursäter, Göran Smedegård
}

\begin{abstract}
The effects of sulphasalazine on the production of second messenger compounds in human granulocytes have been characterised by various stimuli. The increases in cytosolic calcium, inositol trisphosphate, diacylglycerol, and phosphatidic acid (all important mediators of intracellular signal transduction) triggered by stimulation were inhibited by sulphasalazine. The metabolites 5-aminosalicylic acid and sulphapyridine were less potent inhibitors than the mother compound.

It is concluded that sulphasalazine inhibits the synthesis of phosphoinositide derived second messenger compounds at the level of phospholipase $\mathrm{C}$ or its regulatory guanosine 5 '-triphosphate (GTP) binding protein. Inhibition of phosphatidic acid synthesis was either due to the same mechanism, or to interaction with a phospholipase $D$ regulating GTP binding protein.
\end{abstract}

(Ann Rheum Dis 1992; 51: 1230-1236)

Sulphasalazine, a drug used for the treatment of inflammatory bowel disease, ${ }^{1}$ has during the last decade also been shown to treat effectively other diseases of a presumably autoimmune nature, such as rheumatoid arthritis, ankylosing spondylitis, ${ }^{2}$ and psoriasis. ${ }^{3}$

The aetiology of tissue injury in rheumatoid arthritis is unclear. A variety of cells, including granulocytes, have been suggested to contribute to the initiation and propagation of the immune response in the rheumatoid synovium. Kitsis and Weissmann ${ }^{4}$ have reviewed the role of the neutrophil granulocyte as a key player in the articular and extra-articular manifestations of rheumatoid arthritis. They compared rheumatoid joint inflammation to the Arthus reaction, a neutrophil dependent interaction in which repeated exposure to an antigen results in the formation of immune complexes and activation of complement, causing an influx of granulocytes and tissue destruction.

Sulphasalazine has been found to inhibit

Department of

Pharmacology, Kabi

Pharmacia Therapeutics, Uppsala, Sweden

G Carlin

R Djursäter

G Smedegård

Correspondence to:

Dr Gunnar Carlin,

Kabi Pharmacia AB, S-751 82

Uppsala, Sweden.

Accepted for publication

5 June 1992 granulocyte chemotaxis, ${ }^{9}$ lymphocyte proliferation, ${ }^{10}$ and interleukin 2 production ${ }^{11}$ in addition to monocyte production of interleukin $1 .{ }^{12}$
We have previously found by using the granulocyte as a model system that sulphasalazine inhibits cellular activation before activation of protein kinase $C$ by interference with the synthesis of phosphoinositide derived second messenger compounds. ${ }^{6}$ As several cell types utilise phosphoinositide dependent signal transduction, sulphasalazine may modify a principal common mechanism for the regulation of cell activity, which may explain the beneficial effects of the drug in a variety of diseases.

Many of the stimuli used in the earlier studies trigger an increase in cytosolic calcium as part of the activation sequence. The increase in calcium has, in a variety of cell systems, been found to depend on remodelling of phosphoinositides ${ }^{13}$ (see fig 1). Ligation of a cell receptor leads to the phospholipase $\mathrm{C}$ dependent hydrolysis of phosphatidylinositol-4,5-bisphosphate generating two triggers of cell responses, namely diacylglycerol, an activator of protein kinase $\mathrm{C},{ }^{14}$ and inositol-1,4,5-trisphosphate, which triggers the release of cell associated calcium. ${ }^{13}$ The link between the receptor and phospholipase $\mathrm{C}$ is in many cells a guanosine $5^{\prime}$ trisphosphate (GTP) binding protein. ${ }^{15}$

Several drugs have been shown to modulate granulocyte responses such as superoxide production, ${ }^{16}$ and a few studies have indirectly associated the drug action with an interaction with the synthesis of phosphoinositide derived second messenger molecules ${ }^{17} 18$ and the GTP binding protein. ${ }^{19}$

The purpose of this study was to evaluate whether the inhibitory effects of sulphasalazine on cellular activation were related to the production of second messenger compounds. We found that sulphasalazine inhibited the production of inositol-1,4,5-trisphosphate and consequently the increase in cytosolic calcium, which indicated an interaction with either the plasma membrane receptor, the associated GTP binding protein, or the phospholipase $C$. Sulphasalazine still inhibited activation of cells stimulated with guanosine $5^{\prime}-[\gamma$-thio]triphosphate (GTP[S]), a stimulus which bypasses the plasma membrane receptor.

The production of phosphatidic acid, a metabolite of diacylglycerol, the other product of phospholipase $C$ activity, was also inhibited by sulphasalazine in cells unspecifically labelled in the lipid glyceride backbone. Phosphatidic acid is alternatively formed by hydrolysis of phosphatidylcholine; we found that sulphasalazine also inhibited the production of radioactive phosphatidic acid in cells specifically labelled in phosphatidylcholine. 


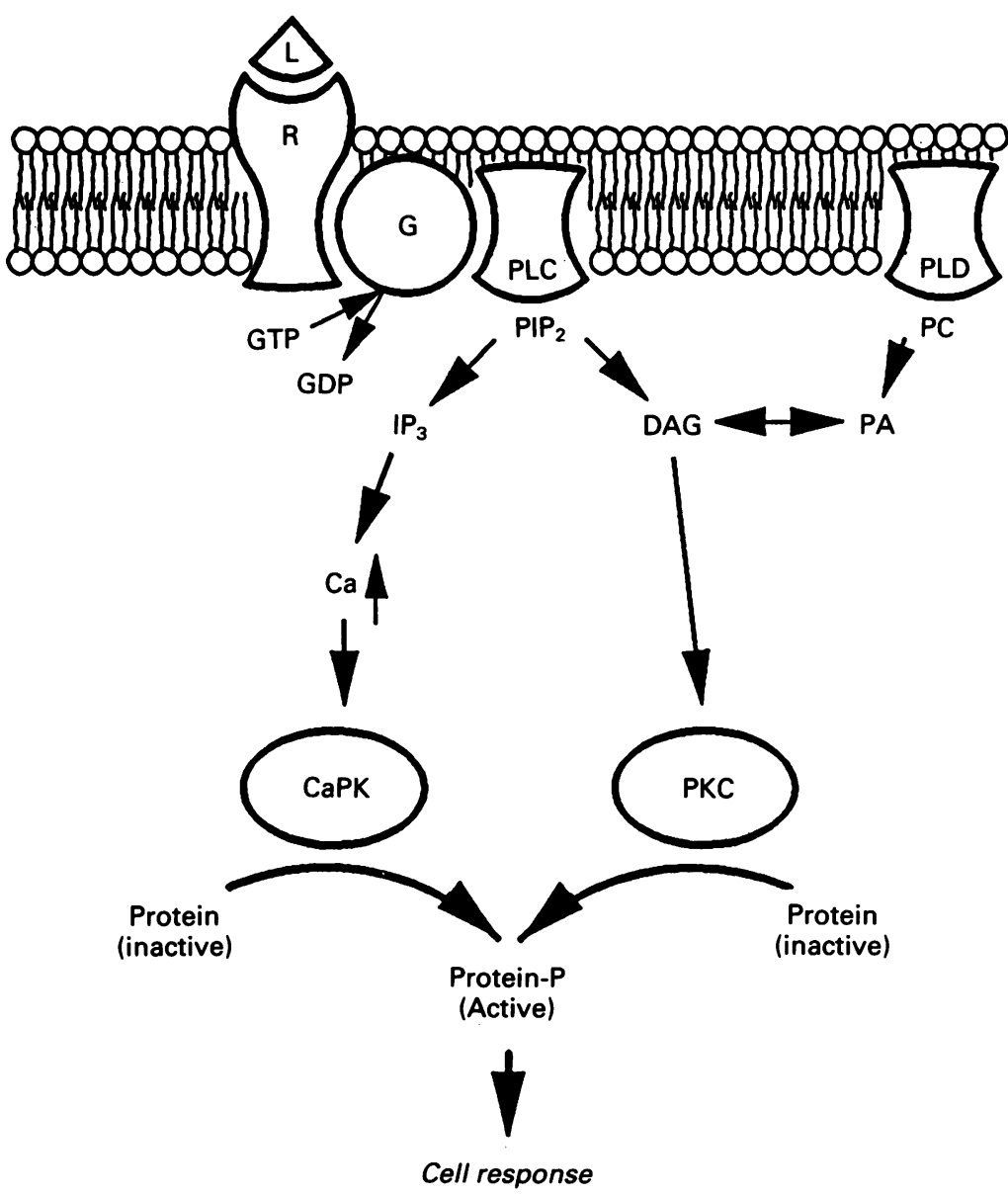

Figure 1 Schematic illustration of the part played by second messenger compounds in the activation of cells. The binding of a ligand $(L)$ to a membrane receptor $(R)$ activates a phospholipase $C(P L C)$ via the action of a guanosine 5'-trisphosphate (GTP) binding protein $(G)$. The activity of the GTP binding protein is regulated by its intrinsic GTPase activity, which hydrolyses GTP and thereby inactivates the protein. By hydrolysis of phosphatidylinositol-4,5-bisphosphate $\left(P I P_{2}\right), P L C$ generates diacylglycerol $(D A G)$, an activator of protein kinase $C(P K C)$, and inositol-1,4,5trisphosphate $\left(\mathrm{IP}_{3}\right)$, which triggers the release of cell associated calcium and the subsequent activation of a protein kinase (CaPK). Diacylglycerol is further phosphorylated to phosphatidic acid (PA). Phosphatidic acid is also formed by a phospholipase D mediated $(P L D)$ hydrolysis of phosphatidylcholine $(P C)$. Phosphatidic acid is subsequently dephosphorylated to DAG. $37^{\circ} \mathrm{C}$ as described previously. ${ }^{21}$ Labelled granulocytes were washed and resuspended in Hanks's balanced salt solution (HBSS, Gibco, Paisley, UK) containing $10 \mathrm{mM} \mathrm{LiCl}$. Each sample, containing $25 \times 10^{6}$ cells in $1 \mathrm{ml}$ HBSS with $\mathrm{LiCl}$, was preincubated with the test compound for 10 minutes at $37^{\circ} \mathrm{C}$ before challenge with $0 \cdot 1 \mu \mathrm{M}$ fMLP (Calbiochem, La Jolla, CA, USA). The reaction was terminated by addition of $7 \cdot 5 \%$ trichloroacetic acid. Inositol1,4,5-trisphosphate was isolated by ion exchange chromatography as decribed previously. ${ }^{21}$

\section{CYTOSOLIC CALCIUM}

The granulocytes, $1 \times 10^{8} / \mathrm{ml}$, were incubated with $10 \mu \mathrm{M}$ FURA-2AM (Molecular Probes Inc., Eugene, OR, USA) as described by Korchak et al. ${ }^{22}$ The FURA-2 loaded cells were suspended to $25 \times 10^{6}$ cells $/ \mathrm{ml}$ in ice cold PBS without $\mathrm{Ca}^{2+}$ and $\mathrm{Mg}^{2+}$ until used.

The cells, $2.5 \times 10^{6} / \mathrm{ml}$ were preincubated in PBS either with or without $\mathrm{Ca}^{2+}$ and $\mathrm{Mg}^{2+}$ (in the latter case the buffer was supplemented with $1 \mathrm{mM}$ EGTA) and test compound for two minutes before the addition of stimulus. Fluorescence changes were monitored in a Shimadzu RF-5000 spectrophotometer equipped with a continuous magnetic stirring device at the dual excitation wavelengths of 340 and $380 \mathrm{~nm}$, and emission at $510 \mathrm{~nm}$. The concentration of cytosolic calcium was calculated by the ratio method of Grynkiewicz et al. ${ }^{23}$

Sulphasalazine at $10 \mu \mathrm{mol} / 1$ had considerable absorbances at 340 and $380 \mathrm{~nm}$. As the reduction of the emitted light was about $25 \%$ at the two wavelengths, however, sulphasalazine had only a negligible effect on the calculations of $\left[\mathrm{Ca}^{2+}\right]$ using the ratio method.

GTP INDUCED SUPEROXIDE PRODUCTION

The granulocytes were electropermeabilised essentially as described by Nasmith et al. ${ }^{24}$ Cells were resuspended in permeabilisation buffer to $10^{7}$ cells $/ \mathrm{ml}$ and permeabilised with two discharges of $5 \mathrm{kV} / \mathrm{cm}$ from a $25 \mu \mathrm{F}$ capacitor by using a Bio-Rad gene pulser apparatus equipped with a $0.8 \mathrm{ml}$ cuvette. Permeabilised cells were used immediately (within a few minutes). The permeabilisation buffer contained $10 \mathrm{mM}$ HEPES, $140 \mathrm{mM} \mathrm{KCl}, 1 \mathrm{mM}$ EGTA, and 0.193 $\mathrm{mM} \mathrm{CaCl}$ (giving a free $\left[\mathrm{Ca}^{2+}\right]$ concentration of $100 \mathrm{nmol} / \mathrm{l}), 1 \mathrm{mM} \mathrm{MgCl}$, and $10 \mathrm{mM}$ glucose (pH 7·0, 295 mosM).

A $133 \mu \mathrm{M}$ solution of cytochrome $c$ (type VI from horse heart, Sigma Chemical, St. Louis, MO, USA) in $750 \mu \mathrm{l}$ permeabilisation buffer containing the test compound was prewarmed to $37^{\circ} \mathrm{C}$. Thereafter $100 \mu$ of a $20 \mathrm{mM}$ NADPH solution was added immediately followed by 50 $\mu l$ of the cell suspension and $100 \mu$ l of GTP[S]. Prolonged exposure of NADPH to cytochrome $c$ will result in the reduction of the latter and was thus avoided. After incubation at $37^{\circ} \mathrm{C}$ the absorbances at 550 and $540 \mathrm{~nm}$ were recorded spectrophotometrically. ${ }^{6}$ The superoxide production was expressed as the difference in absorbance at these wavelengths. ${ }^{6}$ All values 
given are the mean of at least duplicate parallel experiments.

\section{GTPASE ACTIVITY}

Granulocytes were suspended in $0.25 \mathrm{M}$ sucrose, $10 \mathrm{mM}$ HEPES, and $1 \mathrm{mM}$ EGTA (pH 7.5) to about $10^{7}$ cells $/ \mathrm{ml}$. The cell suspension was sonicated with a 10 second pulse of a Branson B15 cell disruptor. Intact cells and nuclei were removed by 10 minutes of centrifugation at 400 $g$, and membranes were sedimented by centrifugation for 30 minutes at $16000 \mathrm{~g}$. Membranes were either used immediately or frozen.

GTPase activity was calculated by measuring the liberation of phosphate-32 from $\left[\gamma-{ }^{32} \mathrm{P}\right]$ GTP as described by Pelz et al. ${ }^{25}$ The reaction mixture contained $10 \mu \mathrm{l}$ cell membrane suspension (membranes from the granulocytes in about $3 \mathrm{ml}$ blood), $100 \mu l$ buffer $(100 \mathrm{mM} \mathrm{NaCl}$, $20 \mathrm{mM}$ TRIS-HCl, $5 \mathrm{mM} \mathrm{MgCl}_{2}, 0.1 \mathrm{mM}$ EGTA, $1.14 \mathrm{mM}$ ATP, $500 \mu \mathrm{M}$ adenylylimidodiphosphate, $0.25 \mathrm{mM}$ ouabain, $\mathrm{pH} \mathrm{7.5)}$ with about $50 \mathrm{nmol} / 1$ added $\left[\gamma-{ }^{32} \mathrm{P}\right]-\mathrm{GTP}$ (NEG004, New England Nuclear, Stockholm, Sweden; $1.22 \mathrm{TBq} / \mathrm{mmol}$ radioactivity). The reaction was terminated after 10 minutes by addition of $0.5 \mathrm{ml}$ of a $5 \%$ charcoal mixture containing $0.1 \%$ dextran 500 (Kabi Pharmacia) and 0.5\% bovine serum albumin in Dulbecco's phosphate buffer. The tubes were vortexed and centrifuged for five minutes at $11000 \mathrm{~g}$, whereafter the phosphate- 32 activity in the supernatant was measured.

SYNTHESIS OF PHOSPHATIDIC ACID IN GLYCEROL LABELLED CELLS

Granulocytes from $70 \mathrm{ml}$ of blood were suspended in $2 \mathrm{ml}$ of HBSS containing $0.5 \mathrm{mM}$ $\mathrm{CaCl}_{2}{ }^{26}$ and incubated for one hour at $37^{\circ} \mathrm{C}$ with $740 \mathrm{kBq}\left[{ }^{3} \mathrm{H}\right]$ glycerol (NET 022, New England Nuclear).

The cells were washed twice and resuspended in HBSS. Cells from two different donors were combined immediately before the experiment.

The cell suspension, $15 \times 10^{6}$ cells in $500 \mu \mathrm{l}$ containing $5 \mu \mathrm{g} / \mathrm{ml}$ of cytochalasin B (Calbiochem) and the test compound as indicated were preincubated for 10 minutes at $37^{\circ} \mathrm{C}$. Thereafter the cells were stimulated by addition of 0.1 or $1 \mu \mathrm{M}$ fMLP. The reaction was terminated by addition of $1.875 \mathrm{ml}$ chloroform/methanol (1:2, $\mathrm{v} / \mathrm{v}$ ) after 60 seconds. To obtain phase separation, $625 \mu \mathrm{l}$ of chloroform and $625 \mu \mathrm{l}$ of water were added. The lower phase containing the phospholipids was collected and evaporated.

For the phosphatidic acid determinations the phospholipids were dissolved in $30 \mu \mathrm{l}$ chloroform/methanol/water (75:25:2, v/v). Exogenous phosphatidic acid, $20 \mu \mathrm{g}$, and phosphatidylinositol, $10 \mu \mathrm{g}$, were added as carriers making the total volume $50 \mu \mathrm{l}$. The phospholipids were separated by thin layer chromatography on Silicagel 60 plates (5715, E. Merck, Darmstadt, Germany) essentially as described previously. ${ }^{26}$ The mobile phase consisted of methyl acetate/ propan-1-ol/chloroform/methanol/0.25 $\mathrm{M} \mathrm{KCl}$ acetic acid $(25: 25: 25: 12: 9: 0 \cdot 062, v / v)$. After the chromatographic separation the phospholipid spots were stained with iodine vapour. The spots corresponding to phosphatidic acid, phosphatidylinositol, and phosphatidylcholine were scraped and counted in a scintillation counter.

\section{PHOSPHOLIPASE D ACTIVITY}

Radiolabelling of granulocytes with $\left[{ }^{3} \mathrm{H}\right]$ alkyllysophosphatidylcholine (octadecyl-lyso platelet activating factor, TRK.745, Amersham, Solna, Sweden), cell activation and analysis were performed essentially as described by Billah et al. ${ }^{27}$ Briefly, $20 \times 10^{6}$ cells $/ \mathrm{ml}$ were suspended in $25 \mathrm{mM}$ HEPES (pH 7.4) with $125 \mathrm{mM} \mathrm{NaCl}$, $0.7 \mathrm{mM} \mathrm{MgCl}, 0.5 \mathrm{mM}$ EGTA, $10 \mathrm{mM}$ glucose, and $1 \mathrm{mg} / \mathrm{ml}$ albumin. Radiolabel, $185 \mathrm{kBq} / \mathrm{ml}$ was added and the suspension was incubated for 75 minutes at $37^{\circ} \mathrm{C}$. After washing, the cells were resuspended to $5 \times 10^{6}$ cells $/ 0.45 \mathrm{ml}$ in HEPES buffer without albumin.

The cells were preincubated with cytochalasin B $(5 \mu \mathrm{g} / \mathrm{ml})$ and test compound for five minutes at $37^{\circ} \mathrm{C}$, after which stimulus was added, either $0 \cdot 1 \mu \mathrm{M}$ fMLP, or $20 \mathrm{mM} \mathrm{NaF}$ plus $30 \mu \mathrm{M} \mathrm{AlCl}_{3}$ or $0.1 \mu \mathrm{M}$ phorbol-12-myristate-13-acetate (PMA, Sigma Chemical). The final sample volume was $500 \mu \mathrm{l}$, containing $5 \times 10^{6}$ cells. The reaction was terminated by addition of $1.875 \mathrm{ml}$ chloroform/methanol/acetic acid (100:200:4, $\mathrm{v} / \mathrm{v})$. Chloroform and water (625 $\mu \mathrm{l}$ of each) were then added to obtain phase separation. The lower phase was collected and evaporated. For the determination of phosphatidic acid and diacylglycerol the phospholipids were dissolved in $30 \mu \mathrm{l}$ chloroform/methanol/water $(75: 25: 2$, $\mathrm{v} / \mathrm{v})$. Phosphatidic acid, $20 \mu \mathrm{g}$, was added as carrier making the total volume $50 \mu \mathrm{l}$. The phospholipids were separated by thin layer chromatography as described by Billah et al, ${ }^{27}$ their solvent systems I and III. After the chromatographic separation the phospholipid spots were stained with iodine vapour. The spots corresponding to phosphatidic acid and diacylglycerol were scraped and counted in a scintillation counter after addition of $0.25 \mathrm{ml}$ methanol and $10 \mathrm{ml}$ Instagel. Counts were corrected for quenching by sulphasalazine.

\section{STATISTICS}

Results are expressed as the mean (SD). Statistical significance was determined using Student's $t$ test. A p value of less than 0.05 was considered significant.

\section{Results}

SYNTHESIS OF INOSITOL-1,4,5-TRISPHOSPHATE

Initial experiments showed that the intracellular concentration of inositol-1,4,5-trisphosphate concentration was at a maximum about 30 seconds after activation with $0 \cdot 1 \mu \mathrm{M}$ fMLP. The radioactivity in the inositol-1,4,5trisphosphate fraction was 79 counts/min before activation and 317,374 , and 175 counts/min 15 , 30 , and 60 seconds after activation in a representative experiment. A reaction time of 30 seconds was therefore chosen for studies of the effects of the drug. 
Table I Inhibition of human granulocyte inositol-1,4,5trisphosphate synthesis by sulphasalazine and its metabolites. The granulocytes were stimulated with $0 \cdot 1 \mu M N$-formyl-I. methionyl-L-leucyl-L-phenylalanine for 30 seconds. Results given as mean $(S D)$

\begin{tabular}{lll}
\hline Test compound & $\begin{array}{l}\text { Concentration } \\
(\mu m o l / l)\end{array}$ & Inhibition $(\%)$ \\
\hline Sulphasalazine & 100 & $45 \cdot 6(11 \cdot 9)(\mathrm{n}=8)$ \\
& 10 & $28 \cdot 5(6 \cdot 4)(\mathrm{n}=2)$ \\
5-Aminosalicylic acid & 100 & $13 \cdot 8(4 \cdot 6)(\mathrm{n}=4)$ \\
Sulphapyridine & 100 & $7 \cdot 5(8 \cdot 2) \quad(\mathrm{n}=4)$
\end{tabular}

Table 1 shows that sulphasalazine ( 10 and 100 $\mu \mathrm{mol} / \mathrm{l})$ inhibited the synthesis of inositol-1,4,5trisphosphate. The metabolites sulphapyridine and 5-aminosalicylic acid at $100 \mu \mathrm{mol} / 1$ inhibited the reaction signficantly less than $10 \mu \mathrm{mol} / \mathrm{l}$ of the mother molecule.

\section{CYTOSOLIC CALCIUM}

Figure 2 shows that a transient increase in cytosolic calcium occurred after stimulation with $\mathrm{FMLP}$. The peak value was reached after about eight to 10 seconds (including time for stirring), and was followed by a less rapid decline. The increase in cytosolic calcium varied between cells from different donors and was 85 (25) $\mathrm{nmol} / \mathrm{l}$ for $1 \mathrm{nM}$ fMLP in the presence of extracellular calcium (12 subjects). In the absence of extracellular calcium it was 70 (17)

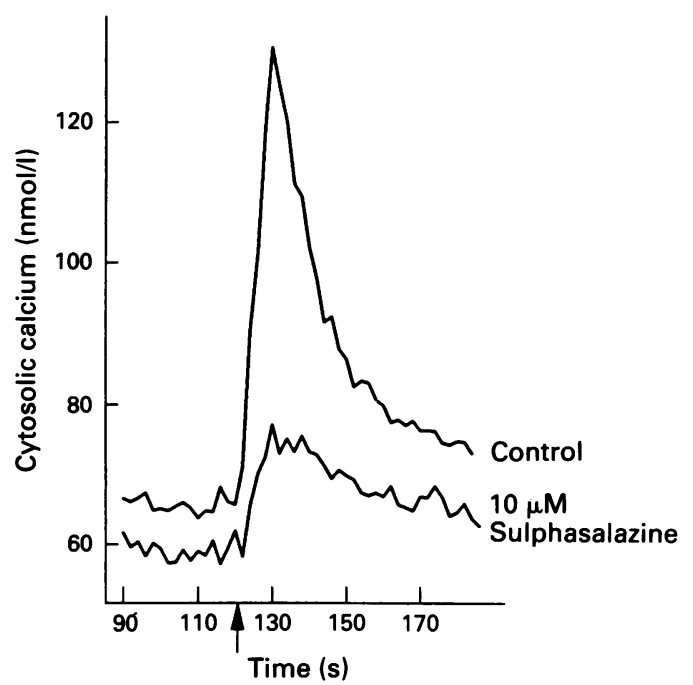

Figure 2 Changes in cytosolic calcium in granulocytes stimulated with $10 \mathrm{nM} N$-formyl-L-methionyl-L-leucyl-Lphenylalanine ( $f M L P)$. Effect of 120 seconds preincubation with $10 \mu M$ suphasalazine. The arrow indicates the addition of $F M L P$.

Table 2 Effect of sulphasalazine and sulphapyridine on the increase of cytosolic calcium in human granulocytes. The results are mean $(S D)$ percentage inhibition of the peak value, which was reached about 10 seconds after addition of the stimulus

\begin{tabular}{|c|c|c|c|}
\hline Stimulus* & $\begin{array}{l}\text { Test } \\
\text { compound }\end{array}$ & $\begin{array}{l}\text { Concentration } \\
(\mu \mathrm{mol} / \mathrm{l})\end{array}$ & Inhibition (\%) \\
\hline $\begin{array}{l}\text { Medium with extracellular } \\
1 \mathrm{nM} \text { fMLP }\end{array}$ & $\begin{array}{l}\mathrm{Ca} \\
\text { Sulphasalazine } \\
\text { Sulphasalazine } \\
\text { Sulphapyridine }\end{array}$ & $\begin{array}{r}5 \\
10 \\
10\end{array}$ & $\begin{array}{l}34 \cdot 2(6 \cdot 3) \quad(n=6) \\
61 \cdot 1(12 \cdot 1)(n=5) \\
12 \cdot 2(7 \cdot 5)(n=4)\end{array}$ \\
\hline $\begin{array}{l}\text { Medium with EGTA, with } \\
\quad 1 \mathrm{nM} \text { fMLP }\end{array}$ & $\begin{array}{l}\text { hout Ca } \\
\text { Sulphasalazine } \\
\text { Sulphasalazine }\end{array}$ & $\begin{array}{r}5 \\
10\end{array}$ & $\begin{array}{l}47 \cdot 8(13 \cdot 7)(n=4) \\
67 \cdot 7(7 \cdot 9) \quad(n=3)\end{array}$ \\
\hline $10 \mathrm{nM}$ fMLP & $\begin{array}{l}\text { Sulphasalazine } \\
\text { Sulphapyridine }\end{array}$ & $\begin{array}{l}10 \\
10\end{array}$ & $\begin{array}{ll}30 \cdot 6(7 \cdot 4) & (\mathrm{n}=7) \\
10 \cdot 5(6 \cdot 0) & (\mathrm{n}=3)\end{array}$ \\
\hline
\end{tabular}

fMLP $=N$-formyl-L-methionyl-L-leucyl-L-phenylalanine. $\mathrm{nmol} / \mathrm{l}$ (six subjects) and $126(69) \mathrm{nmol} / \mathrm{l}$ (nine subjects) respectively for 1 and $10 \mathrm{nM}$ fMLP.

Table 2 shows that sulphasalazine inhibited the increase in cytosolic calcium. At a concentration of only $5 \mu \mathrm{mol} / \mathrm{l}$ almost $50 \%$ of the response to $1 \mathrm{nM}$ fMLP was inhibited in the absence of extracellular calcium. Sulphapyridine was considerably less potent. 5Aminosalicylic acid was not studied due to its substantial intrinsic fluorescence at the excitation wavelengths applied.

\section{GTP INDUCED SUPEROXIDE PRODUCTION}

Electropermeabilised granulocytes stimulated with GTP[S] (tetralithium salt, $50 \mu \mathrm{mol} / \mathrm{l}$ ) produced enough superoxide to reduce $8 \cdot 1$ nmol cytochrome $c$ for each 500000 cells (table 3 ). The production of superoxide after stimulation with $10 \mu \mathrm{M}$ GTP[S] was slightly less, or 6.8 nmol for each 500000 cells.

The superoxide production was inhibited in the presence of sulphasalazine $(100 \mu \mathrm{mol} / \mathrm{l})$. The inhibition varied between blood donors and was more pronounced after stimulation with $10 \mu \mathrm{M}$ GTP[S] (43-87\% inhibition) than with $50 \mu \mathrm{M}$ GTP[S] (23-39\% inhibition). GTP[S] did not stimulate superoxide production in intact (not electropermeabilised) cells (not shown).

In the original method, ${ }^{24} 1 \mathrm{mM}$ ATP was added to the reaction mixture. Exogenous ATP is, however, known to activate ${ }^{28}$ granulocytes leading to formation of inositol phosphates and an increase in $\mathrm{Ca}^{2+}$, and to prime granulocytes for enhanced superoxide production after fMLP stimulation. ${ }^{29}$ Favourably, in contrast to Nasmith et $a l^{24}$ and in agreement with Hartfield and Robinson, ${ }^{30}$ we found that the superoxide production did not require exogenously added ATP.

GTPASE ACTIVITY OF GRANULOCYTE MEMBRANES The GTPase activity in the presence of $50 \mathrm{nM}$ GTP was $0.63(0 \cdot 10) \mathrm{nmol}$ of released phosphate in the absence and $0.57(0.14) \mathrm{nmol}$ in the presence of $100 \mu \mathrm{M}$ sulphasalazine (four samples). No significant inhihition was thus seen in the presence of sulphasalazine.

SYNTHESIS OF PHOSPHATIDIC ACID IN GLYCEROL LABELLED CELLS

The response to stimulation with fMLP varied considerably between cells from different donors. The relative increase of radioactivity in the phosphatidic acid band 60 seconds after fMLP stimulation was $1 \cdot 74(0 \cdot 22)$ fold (seven

Table 3 Effect of $100 \mu M$ sulphasalazine on superoxide production by electropermeabilised human granulocytes stimulated with guanosine 5 '-[ $\gamma$-thio] triphosphate

(GTP[S]). The superoxide production is

expressed in nanomol reduction of cytochrome c per sample containing 500000 cells. Results are given as mean $(S D)$ $(n=4)$

\begin{tabular}{llll}
\hline Stimulus & Control & Sulphasalazine & Inhibition $(\%)$ \\
\hline $10 \mu M$ GTP[S] & $6 \cdot 8(1 \cdot 7)$ & $2 \cdot 3(1 \cdot 1)$ & $66(19)$ \\
$50 \mu \mathrm{M}$ GTP[S] & $8 \cdot 1(1 \cdot 3)$ & $5 \cdot 6(1 \cdot 4)$ & $31(8)$ \\
\hline
\end{tabular}


Table 4 Inhibition of human granulocyte phosphatidic acid synthesis by sulphasalazine and metabolites. The glycerol labelled granulocytes were stimulated with $0 \cdot 1 \mu M N$ formyl-L--methionyl-L-leucyl-L-phenylalanine for 60 seconds The inhibition is expressed as mean $(S D)$ percentage of the phosphatidic acid synthesis in the absence of test compound

\begin{tabular}{lll}
\hline Test compound & $\begin{array}{l}\text { Concentation } \\
(\mu m o l / l)\end{array}$ & Inhibition $(\%)$ \\
\hline Sulphasalazine & 100 & $66 \cdot 5(18 \cdot 6)(n=14)$ \\
& 30 & $42 \cdot 5(27 \cdot 6)(n=4)$ \\
& 10 & $38 \cdot 9(19 \cdot 0)(n=8)$ \\
& 3 & $26 \cdot 3(8 \cdot 4)(n=4)$ \\
5-Aminosalicylic acid & 100 & $31 \cdot 2(15.3)(n=4)$ \\
Sulphapyridine & 100 & $38 \cdot 8(18 \cdot 2)(n=4)$ \\
\hline
\end{tabular}

samples) for $1 \mu \mathrm{M}$, and $1.73(0.42)$ fold (29 samples) for $0 \cdot 1 \mu \mathrm{M}$ fMLP.

Sulphasalazine $(100 \mu \mathrm{mol} / \mathrm{l})$ inhibited the increase in phosphatidic acid after stimulation with fMLP $(1 \mu \mathrm{mol} / \mathrm{l}$ ) by 54 (14)\% (seven samples). At $0 \cdot 1 \mu \mathrm{M}$ fMLP, the inhibition in the presence of $100 \mu \mathrm{M}$ sulphasalazine was 67 (19)\%, and the inhibition was dose dependent with respect to sulphasalazine (table 4). The metabolites sulphapyridine and 5-aminosalicylic acid inhibited phosphatidic acid synthesis only about one tenth as potently as sulphasalazine.

\section{SYNTHESIS OF PHOSPHATIDIC ACID AND DIACYLGLYCEROL IN PHOSPHATIDYLCHOLINE LABELLED CELLS}

The phospholipase $\mathrm{D}$ mediated synthesis of phosphatidic acid after stimulation with $0 \cdot 1 \mu \mathrm{M}$ fMLP varied considerably between cells from different donors (fig 3A). Initial experiments

Table 5 Effects of sulphasalazine and metabolites on phosphatidic acid and diacylglycerol synthesis by human granulocytes radiolabelled in phosphatidyl choline. Results are mean $(S D)$ percentage inhibition

\begin{tabular}{|c|c|c|c|c|}
\hline Stimulus & $\begin{array}{l}\text { Reaction time } \\
(s)\end{array}$ & Test compound & $\begin{array}{l}\text { Concentration } \\
(\mu \mathrm{mol} / \mathrm{l})\end{array}$ & $\begin{array}{l}\text { Inhibition } \\
(\%)\end{array}$ \\
\hline $\begin{array}{l}\text { Inhibition of phosph } \\
100 \mathrm{nM} \text { fMLP* }\end{array}$ & $\begin{array}{l}\text { tidic acid } \\
30 \\
30 \\
120 \\
120 \\
30 \\
30\end{array}$ & $\begin{array}{l}\text { Sulphasalazine } \\
\text { Sulphasalazine } \\
\text { Sulphasalazine } \\
\text { Sulphasalazine } \\
\text { Sulphapyridine } \\
\text { 5-Aminosalicylic acid }\end{array}$ & $\begin{array}{r}10 \\
100 \\
10 \\
100 \\
100 \\
100\end{array}$ & $\begin{array}{l}36 \cdot 0(1 \cdot 7) \quad(n=3) \\
89 \cdot 6(5 \cdot 7) \quad(n=5) \\
21 \cdot 3(12 \cdot 9)(n=3) \\
83 \cdot 3(5 \cdot 5) \quad(n=3) \\
28 \cdot 6(11 \cdot 4)(n=5) \\
-2 \cdot 3(14 \cdot 5)(n=3)\end{array}$ \\
\hline 100 nM PMA* & 300 & Sulphasalazine & 100 & $0.3(0.5) \quad(n=2)$ \\
\hline $20 \mathrm{mM} \mathrm{NaF}$ & 300 & Sulphasalazine & 100 & $56 \cdot 0(24 \cdot 5)(n=3)$ \\
\hline $\begin{array}{l}\text { Inhibition of diacyl } \\
100 \mathrm{nM} \text { fMLP }\end{array}$ & $\begin{array}{r}\text { cerol } \\
120 \\
120\end{array}$ & $\begin{array}{l}\text { Sulphasalazine } \\
\text { Sulphasalazine }\end{array}$ & $\begin{array}{r}10 \\
100\end{array}$ & $\begin{array}{l}43.3(1.5)(n=3) \\
97.7(13.6)(n=3)\end{array}$ \\
\hline
\end{tabular}

*fMLP $=N$-formyl-L-methionyl-L-leucyl-L-phenylalanine; $P M A=$ phorbol-12-myristate-13-acetate.

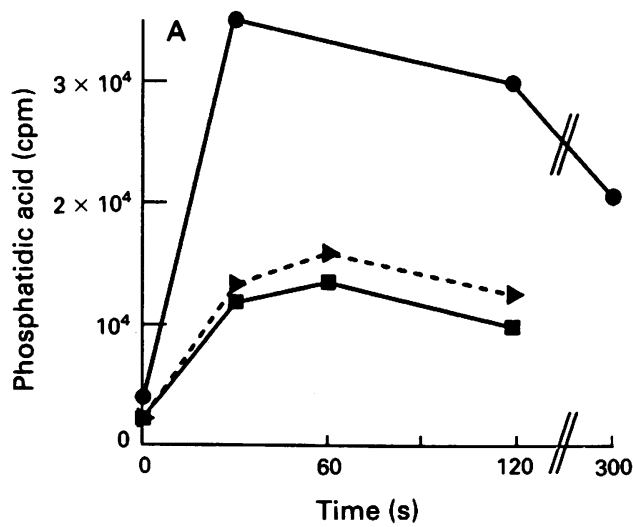

showed that the maximum concentration of phosphatidic acid was obtained after 30-60 seconds, which agrees with earlier data. ${ }^{27}$ Table 5 shows that sulphasalazine $(100 \mu \mathrm{mol} / \mathrm{l})$ was a potent inhibitor of phosphatidic acid formation after 30 and 120 seconds, also $10 \mu \mathrm{M}$ sulphasalazine inhibited the reaction significantly. Sulphapyridine $(100 \mu \mathrm{mol} / \mathrm{l})$ inhibited the reaction slightly whereas 5-aminosalicylic acid was inactive.

Phosphatidic acid is metabolised to diacylglycerol $^{27}$ and the diacylglycerol synthesis consequently lagged behind the phosphatidic acid synthesis (fig 3B) in time, which agrees with earlier results. ${ }^{31}$ The synthesis of diacylglycerol was inhibited by sulphasalazine (table 5).

An accelerating increase in the concentration of phosphatidic acid after stimulation with 20 $\mathrm{mM}$ fluoride was seen for at least $\mathbf{1 0}$ minutes. Table 5 shows that $100 \mu \mathrm{M}$ sulphasalazine inhibited the synthesis of phosphatidic acid by $56 \%$ after five minutes of stimulation.

Phosphatidic acid was produced in cells activated with PMA, essentially as described previously. ${ }^{31}$ No inhibitory effect of $100 \mu \mathrm{M}$ sulphasalazine was found after five minutes (table 5).

\section{Discussion}

This study has shown that sulphasalazine inhibits the activation of human granulocytes through inhibition of the production of second messenger compounds derived from the GTP binding protein mediated activation of phospholipases $C$ and $D$.

In the first set of experiments it was shown that sulphasalazine inhibited the phospholipase C dependent synthesis of inositol1,4,5-trisphosphate from phosphatidylinositol4,5-bisphosphate as well as the increase in cytosolic calcium in granulocytes. The latter inhibition may be secondary to the inhibition of inositol-1,4,5-trisphosphate synthesis, as cytosolic calcium is released by the action of inositol-1,4,5-trisphosphate. When a low concentration of fMLP ( $1 \mathrm{nmol} / \mathrm{l})$ was used to stimulate the release of intracellular calcium, the inhibitory potency of sulphasalazine was increased (table 2). A similar finding was reported by Carlin et $a l^{6}{ }^{6}$ where it was found

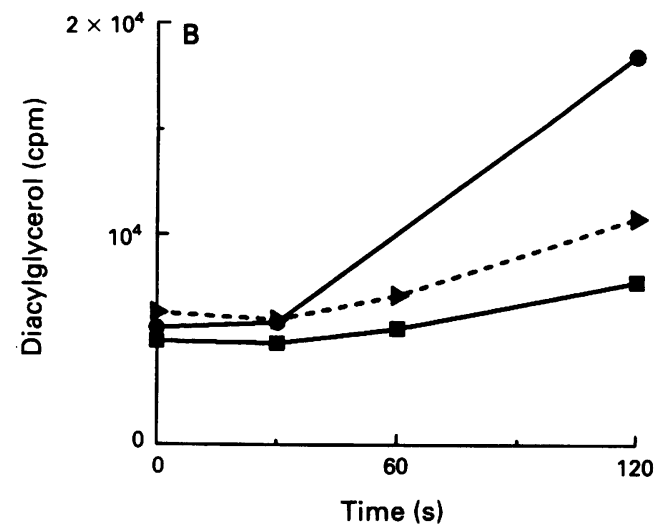

Figure 3 Changes in phosphatidic acid $(A)$ and diacylglycerol $(B)$ in human granulocytes stimulated with $100 \mathrm{nM}$ $N$-formyl-L-methionyl-L-leucyl-L-phenylalanine. The cells were labelled with lysophosphatidylcholine. Results are of experiments using blood from three different donors. 
that sulphasalazine inhibited granulocyte superoxide production better at lower fMLP concentrations. Kanerud et $a^{32}$ found, by using a single excitation wavelength, that $10 \mu \mathrm{M}$ sulphasalazine inhibited the increase in cytosolic calcium in granulocytes stimulated with $100 \mathrm{nM}$ fMLP.

These inhibitory effects of sulphasalazine showed that the drug affected the intracellular signalling system either at the level of plasma membrane receptor, the GTP binding protein coupled to the receptor, or the enzymatic activity of phospholipase C. ${ }^{15}$

The first possibility (suggested by Stenson et $a l^{7}$ ) was addressed in experiments using electropermeabilised granulocytes activated with the GTP analogue GTP[S], thus bypassing the plasma membrane receptors. Sulphasalazine did inhibit the granulocyte activation with GTP[S], which revealed that the drug effect was not due to interaction with the plasma membrane receptor for fMLP. Inhibition of the fMLP receptor as the major effect of sulphasalazine is unlikely, as earlier studies have shown that the drug inhibits cell activation by several receptor dependent stimuli other than fMLP, such as immune complexes ${ }^{8}$ and zymosan. $^{5}$

Phospholipase $\mathrm{C}$ is considered to be activated by the $\alpha$ subunit of the GTP binding protein. This protein is active when associated with a molecule of GTP, and deactivation is accomplished by hydrolysis of the GTP by an intrinsic GTPase activity. ${ }^{15}$ It is thus possible that sulphasalazine inhibits granulocyte activation by enhancing the hydrolysis of GTP. No effect of sulphasalazine on the GTPase activity was noted in the experiments designed to study this function, however.

The two products of phospholipase C mediated degradation of phosphatidylinositol4,5-bisphosphate, inositol-1,4,5-trisphosphate and diacylglycerol, are considered to be the major intracellular signalling substances produced by the cells as a response to fMLP stimulation. ${ }^{13}$ In addition, the importance of phosphatidic acid for cell activation has attracted attention. It is likely that hydrolysis of phosphatidylcholine to phosphatidic acid is of physiological importance as a signal transduction pathway in the activation of, for example, granulocytes, ${ }^{33} 34$ which emphasises that the phosphatidic acid is more than a precursor, or a metabolite, of diacylglycerol.

The synthesis of phosphatidic acid by granulocytes labelled with glycerol was inhibited by sulphasalazine, thus confirming. our earlier results using cells labelled with phosphate-32. ${ }^{6}$ As in these earlier measurements, the recorded phosphatidic acid was mainly derived from diacylglycerol phosphorylated with phosphate32 by the action of diacylglycerol kinase, the effect of sulphasalazine might have been due to inhibition of either the diacylglycerol kinase or to the synthesis of diacylglycerol.

The inhibition of the phosphatidic acid synthesis by sulphasalazine was similar in magnitude in cells with unspecifically (glycerol) labelled phospholipids and in cells specifically labelled in phosphatidylcholine. This similarity agrees with some studies which have shown that almost all the diacylglycerol formed during cell activation emanates from dephosphorylation of phosphatidic acid produced by phospholipase D mediated hydrolysis of phosphatidylcholine. ${ }^{27}$

The effects of sulphasalazine on phospholipase $\mathrm{D}$ mediated degradation of phosphatidylcholine were studied by specific labelling of this phospholipid. Sulphasalazine inhibited the synthesis of phoshatidic acid and the subsequent formation of diacylglycerol in cells activated with fMLP. Fluoride induced activation was also inhibited, again demonstrating that the effect of sulphasalazine was not interaction with a plasma membrane receptor. Sulphasalazine did not inhibit PMA induced phospholipase D activity, which clearly shows that the drug did not inhibit phospholipase D, but interfered with an earlier step in the fMLP and fluoride induced activation of this enzyme.

The mechanisms of hormone induced phosphatidylcholine hydrolysis are not known to the same extent as for phosphoinositide hydrolysis. Stimulation of granulocytes with fMLP or fluoride induces phospholipase D mediated phosphatidylcholine hydrolysis in addition to phospholipase $\mathrm{C}$ mediated hydrolysis of phosphatidylinositol-4,5-bisphosphate. As cell stimulation with calcium ionophores and protein kinase $\mathrm{C}$ activating phorbol esters activates phospholipase $D$ without phospholipase $C$ involvement, ${ }^{31}$ it is possible that phospholipase $\mathrm{D}$ activation requires previous phospholipase $\mathrm{C}$ mediated hydrolysis of phosphatidylinositol4,5-bisphosphate, leading to protein kinase C activation by diacylglycerol and increased cytosolic $\mathrm{Ca}^{2+}$ by inositol-1,4,5-trisphosphate. ${ }^{35}$ If so, the inhibition of sulphasalazine or the synthesis of phosphatidylcholine derived phosphatidic acid seen in this study is the consequence of a previous inhibition of phospholipase C. Alternatively, phospholipase D may not require previous phospholipase $\mathrm{C}$ activity but may be linked to a GTP binding protein, perhaps different from that linked to phospholipase $C,{ }^{35}{ }^{36}$ with the possibility that sulphasalazine may also interact with this GTP binding protein.

It can be concluded from the results of this study that sulphasalazine inhibited cellular activation by interaction with the synthesis of phosphoinositide derived second messenger compounds at the level of phospholipase $C$ or its regulatory GTP binding protein. Sulphasalazine also inhibited the synthesis of the putative second messenger phosphatidic acid, which may be due to either the same mechanism, or by interaction with a phospholipase $D$ regulating GTP binding protein. The metabolites of sulphasalazine, 5-aminosalicylic acid and sulphapyridine, were less potent inhbitors than the mother compound.

1 Peppercorn M A. Sulfasalazine. Pharmacology, clinical use, toxicity, and related new drug development. Ann Intern Med 1984; 101: 377-86.

2 Buxbaum J. Sulfasalazine in arthritis: current practice and future directions. Intern Med Spec 1990; 11: 79-90. 3 Gupta A K, Ellis C N, Siegel M T, et al. Sulfasalazin improves psoriasis. Arch Dermatol 1991; 126: 487-93.

4 Kitsis E, Weissmann G. The role of the neutrophil in rheumatoid arthritis. Clin Orthop 1991; 265: 63-72. 
5 Molin L, Stendahl 0 . The effect of sulfasalazine and its active components on human polymorphonuclear leucocyte function in relation to ulcerative colitis. Acta Med Scand 1979; 206: 451-7.

6 Carlin G, Djursäter R, Smedegård G. Inhibitory effects of sulfasalazine and related compounds on superoxide production by human Production by human polymorph

7 Stenson W F, Mehta J, Spilberg I. Sulfasalazine inhibition of binding of $\mathrm{N}$-formyl-methionyl-leucyl-phenylalanine (FMLP) to its receptor on human neutrophils. Biochem (FMLP) to its receptor on hum

8 Neal $T M$, Vissers $C M$, Winterbourn C C. Inhibition by nonsteroidal anti-inflammatory drugs of superoxide production and granule enzyme release by polymorphonuclear leukocytes stimulated with immune complexes or formyl-methionyl-leucyl-phenylalanine. Biochem Pharmacol 1987; 36: 2511-7.

9 Rhodes J M, Bartholomew T C, Jewell D P. Inhibition of leucocyte motility by drugs used in ulcerative cholitis. Gut 1981; 22: 642-7.

10 Comer S S, Jasin H E. In vitro immunomodulatory effects of sulfasalazine and its metabolites. $\mathcal{f}$ Rheumatol 1988; 15: $580-6$.

11 Fujiwara M, Mitsui K, Yamamoto I. Inhibition of proliferative responses and interleukin 2 productions by salazosulfapyridine
$121-31$.

12 Okamoto M, Sasano M, Goto M, et al. Suppressive effect of anti-rheumatic drugs on interleukin- $1 \beta$ release from human peripheral blood monocytes. Int $\mathcal{F}$ Immunopharmacol 1991; 13: $39-43$.

13 Berridge M J, Irvine R F. Inositol trisphosphate, a novel second messenger in cellular signal transduction. Nature 1984; 312: 315-21.

14 Nishizuka Y. Studies and perspectives of protein kinase C. Science 1986; 233: 305-12.

15 Harnett M M, Klaus G G B. G protein regulation of receptor signalling. Immunol Today 1988; 9: 315-20.

16 Cross A R. Inhibitors of the leukocyte superoxide generating oxidase: mechanism of action and methods for their elucidation. Free Radic Biol Med 1990; 8: 71-93.

17 Wright C D, Kuipers P J, Hoffmann M D, Thueson D O, Conroy M C. Inhibition of human neutrophil activation by the allergic mediator release inhibitor, CI-949. Biochem Biophys Res Commun 1990; 167: 828-34.

18 Hurst N P, French J K, Gorjatschko L, Betts W H. Studies on the mechanism of inhibition of chemotactic tripeptide
stimulated human neutrophil polymorphonuclear leucocyte superoxide production by chloroquine and hydroxychloroquine. Ann Rheum Dis 1987; 46: 750-6.

19 Abramson S B, Leszczynska-Piziak J, Haines K, Reibman J. Non-steroidal anti-inflammatory drugs: effect on a GTP binding protein within the neutrophil plasma membrane. Biochem Pharmacol 1991; 41: 1567-73.

20 Böyum A. Isolation of mononuclear cells and granulocytes from human blood. Scand $\mathcal{F}$ Clin Lab Invest 1968; 21 (suppl 97): 77-89.

21 Rossi F, Della Bianca V, Grzeskowiak M, Bazzoni F. Studies on molecular regulation of phagocytosis in neutrophils. f Immunol 1989; 142: 1652-60.

22 Korchak H M, Vosshall L B, Zagon G, Ljubich T, Rich A M, Weissmann G. Activation of the neutrophil by calcium-mobilizing ligands. $7 \mathrm{Biol}$ Chem 1988; 263: $11090-7$.

23 Grynkiewicz G, Poenie M, Tsien R Y. A new generation of $\mathrm{Ca}^{2+}$ indicators with greatly improved fluorescence properties. F Biol Chem 1985; 260: 3440-50.

24 Nasmith P E, Mills G B Grinstein S. Guanine nucleotides induce tyrosine phosphorylation and activation of the induce tyrosine phosphorylation and activation of the 893-7.

25 Pelz C, Matsumoto T, Molski T F P, Becker E L, Sha'afi R. Characterization of the membrane-associated GTPase activity: effects of chemotactic factors and toxins. $\mathcal{f}$ Cell Biochem 1989; 39: 197-206.

26 Della Bianca V, De Togni P, Grzeskowiak M, Vicentini L M, Di Virgilio F. Cyclic AMP inhibition of phosphoinositide turnover in human neutrophils. Biochim Biophys Acta 1986; 886: 441-7.

27 Billah M M, Eckel S, Mullmann T J, Egan R W, Siegel M I Phosphatidyicholine hydrolysis by phospholipase $\mathrm{D}$ deter-
mines phosphatidate and diglyceride levels in chemotactic mines phosphatidate and diglyceride levels in chemotactic 264: 17069-77.

28 Cockcroft S, Stutchfield J. ATP stimulates secretion in human neutrophils and HL60 cells via a pertussis toxinsensitive guanine nucleotide-binding protein coupled to phospholipase C. FEBS Lett 1989; 245: 25-9.

29 Ward P A, Cunningham T W, Walker B A M, Johnson K J. Differing calcium requirements for regulatory effects of ATP, ATPgammas and adenosine on $\mathrm{O}_{2}$-reponses of human neutrophils. Biochem Biophys Res Commun 1988; 154: 746-51.

30 Hartfield P J, Robinson J M. Fluoride-mediated activation of the respiratory burst in electropermeabilized neutrophils. the respiratory burst in electropermeabilized
Biochim Biophys Acta 1990; 1054: 176-80.

31 Agwu D E, McPhail L C, Chabot M C, Daniel L W, Wykle R L, McCall C E. Choline-linked phosphoglycerides. A source of phosphatidic acid and diglycerides in stimulated source of phosphatidic acid and diglycerides in

neutrophils. F Biol Chem 1989; 264: 1405-13.
32 Kanerud L, Hafström I, Ringertz B. Effect of sulphasalazine and sulphapyridine on neutrophil superoxide production: role of cytosolic free calcium. Ann Rheum Dis 1990; 49: $296-300$.

33 Korchak H M, Vosshall L B, Haines K A, Wilkenfeld C, Lundquist K F, Weissmann G. Activation of the human neutrophil by calcium-mobilizing ligands II. $\mathcal{F}$ Biol Chem 1988; 263: 11098-105.

34 Agwu D E, McPhail L C, Sozzani S, Bass D A, McCall C E. Phosphatidic acid as a second messenger in human polymorphonuclear leukocytes. 7 Clin Invest 1991; 88: 531-9.

35 Billah M M, Anthes J C. The regulation and cellular functions of phosphatidylcholine hydrolysis. Biochem $\mathcal{f}$ 1990; 269: 281-91.

36 Anthes J C, Wang P, Siegel M I, Egan R W, Billah M. Granulocyte phospholipase $D$ is activated by a guanine nucleotide dependent protein factor. Biochem Biophys Res Commun 1991; 175: 236-43. 